\title{
Halting Biological Invasions in Europe: from Data to Decisions. A message from NEOBIOTA 2012
}

\author{
Bernardo Zilletti', Laura Capdevila-Argüelles' \\ I GEIB Grupo Especialista en Invasiones Biológicas, Tarifa 7, 24193 Navatejera (León), Spain \\ Corresponding authors: Bernardo Zilletti and Laura Capdevila-Argüelles (geib.uc@gmail.com)
}

Academic editor: I. Kühn | Received 18 February 2014 | Accepted 20 February 2014 | Published 17 April 2014

Citation: Zilletti B, Capdevila-Argüelles L (2014) Halting Biological Invasions in Europe: from Data to Decisions. A message from NEOBIOTA 2012. In: Capdevila-Argüelles L, Zilletti B (Eds) Proceedings of 7th NEOBIOTA conference, Pontevedra, Spain. NeoBiota 21: 1-5. doi: 10.3897/neobiota.21.7289

\section{Introduction}

The NEOBIOTA conferences initiated by the European Group on Biological Invasions represents a forum for exchange of ideas and discussion of topics related to biological invasions as well as an interface between science, application and policies (Kowarik and Starfinger 2009). The $7^{\text {th }}$ NEOBIOTA conference (http://neobiota2012.blogspot. com.es/), held in Pontevedra (Spain) from 12-14 September 2012, brought together 288 participants (ecologists, conservationists, representatives of governmental agencies and stake-holders), from 24 European countries and 9 non-European ones (namely, Australia, Brazil, Canada, Chile, Colombia, New Zealand, South Africa, United States and Venezuela).

Keynote lectures offered a substantial look and provided new perspective at the topic. Darren Kriticos (CSIRO Ecosystem Sciences, Australia) presented the recent advances in bioeconomic techniques for pest risk assessment that can inform efforts to prevent the spread of IAS to new regions, or to manage their subsequent spread in the new environment and addressed frontier issues for the application of these techniques more broadly under current and future climates. Gregory Ruiz (Smithsonian Institute, USA) gave an overview on how non-native species richness for invertebrates changes along the latitudinal gradient and on mechanisms that may explain the observed pattern in marine systems highlighting their relevance for evaluating effects on coastal marine 
ecosystems and advancing management strategies to limit invasion impacts. Dave Richardson (Centre of Invasion Biology at the University of Stellenbosch, South Africa) gave a global snapshot of the current status of alien tree invasions and the problems they cause; reviewed some approaches and strategies that have evolved to deal with invasive alien trees in different parts of the world; and offered some ideas on potentially useful strategies for developing more effective and sustainable strategies for management.

Oral and poster sessions, structured around 4 main topics (ecology, evolution, impacts and management of biological invasions) provided the framework for in-depth debates on theoretical and applied aspects dealing with biological invasions, and wider discussions on what can be done to halt the problem. Around 290 scientific contributions covering a wide range of organisms and ecosystems addressed the current state of knowledge about interactions of climate change with biological invasions, modelling the success of alien species, species traits conferring invasiveness, biotic and environmental control of biological invasions, genetics and evolution of introduced and native populations, ecological impacts, new tools for prevention and early detection of invasive species, routes, pathways and vectors of invasions, risk analysis and control and eradication of invasive species.

At the end of the conference participants called once again the attention on the progressing and escalating threats posed by invasive alien species in Europe and suggested that immediate cooperative, specific policies are needed if we are to have any chance to halt biodiversity loss. In accordance with the Neobiota 2012 slogan "Halting Biological Invasions in Europe: from Data to Decisions" which emphasizes the need of bridging science and policy to deal effectively with invasive alien species, a resolution entitled "Time to act! Biological invasions need a strong European legal framework urgently!" was adopted by participants and later delivered to European Authorities (see Suppl. material 1).

The scientific research is contributing significantly to the management of invasive alien species and our understanding of the complexity of the processes underlying biological invasions. But, there remain challenges and questions which require novel approaches, multidisciplinarity, new techniques from different fields and cooperative efforts both in theoretical and applied research. Some of them are approached in this Special Issue.

There is a strong interest to understand why some species are successful in invading new environments and others not. Several hypotheses have been proposed to explain invasion success on the basis of intrinsic biological traits and extrinsic eco-evolutionary differences between the native and introduced ranges. However, their applicability is up for debate in the scientific arena.

Within this framework Colautti et al. (2014a) provide a novel way to quantify the invasiveness of species taking into account (i) interspecific differences in performance among native and introduced species within a region, and (ii) intraspecific differences between populations of a species in its native and introduced ranges. The authors demonstrate how inter- and intraspecific comparisons using field surveys can improve testing of the major hypotheses of invasion success, and highlight the need for large-scale 
sampling efforts quantifying simple performance measurements in a large number of populations across entire native and introduced distributions.

Large-scale research networks can be a powerful tool to fill this gap permitting the collection of spatially extensive ecological data using minimal resources. Therefore, Colautti et al. (2014b), aiming at establishing Alliaria petiolata as a model species for plant invasion biology, introduce the Global Garlic Mustard Field Survey, a coordinated distributed field survey to collect performance data and germplasm from this species across its entire distribution. They describe constraints on protocol design and implementation, summarize the extent of participation, outline results, and note potential avenues for future research on other invasive species.

Comparisons between native and non-native populations of a species can provide help to clarify the biological and environmental factors that may contribute to range expansion and/or adaptation to climate change, and to reveal mechanisms by which organisms respond to novel ecological and environmental pressures. Moralez-Silva and Del Lama (2014) contribute to clarify the process of colonization and dispersal patterns of the cattle egret (Bubulcus ibis) across its native (Africa) and invaded range (Brazil). By means of genetic tools (Mitochondrial DNA analysis) the authors evaluate and describe the genetic diversity of the species in both areas, the genetic differentiation between populations in different regions of Brazil and Africa as well as the genetic signs of demographic expansion in both areas.

Lastly Abbas et al. (2014) worked on the effects of plant debris (wrack) burial on seed germination and seedling establishment of Spartina densiflora an invasive plant of saltmarshes in southern Europe, Northwest Africa and the West Coast of North America. Experimental results in accordance with field observations show an inverse relationship between germination and emergence of $S$. densiflora with wrack burial. With these findings authors provide useful information to predict invasion dynamics of the species and plan the management of invaded marshes.

Summarizing, the papers of this Special Issue illustrate the enormous complexity intrinsic to biological invasions and set out new challenges in order to improve our understanding of the issue and contribute to best knowledge management of invasive alien species.

\section{Acknowledgements}

The Grupo Especialista en Invasiones Biológicas GEIB is particularly grateful for the support it received for this event. First and foremost to Montserrat Vilà and Emili García-Berthou for their involvement in the Organizing Committee and their words of support and encouragement and for Ingo Kowarik's endorsement of the NEOBIOTA 2012 development and results and for putting their trust in the GEIB, but also to all the members of the Scientific Committee and invited speakers for their tireless work and cooperation. The GEIB would also like to express its gratitude to: the Pazo da Cultura de Pontevedra and the Concello of Pontevedra for providing the venue of 
the conference, technical equipment and always-helpful staff, secondly, the Xunta de Galicia Consellería de Medio Ambiente Territorio e Infraestruturas, Parque Nacional Marítmo Terrestre das Illas Atlánticas de Galicia and Fundació Privada Girona Universitat I Futur. Likewise we are very grateful to the ISSG/IUCN, The Bern Council, Estación Biológica de Doñana and the Universitat de Girona Institut d'Ecologia Aquàtica for their patronage. And last, but certainly not least, the GEIB wishes also to thank wholeheartedly all contributors and participants of Neobiota 2012 for making it a successful event as well as an enjoyable one. This would not have been possible without all the members of the Green Team (Cristina Viñuela, Jose M. Rodríguez, Jose Pintos, Marta Mińambres, Paula Otero, Teresa A. Rodríguez, Vitoriano Rivas, Víctor Á. Suárez). Thanks are due to them for their excellent organisational work.

\section{References}

Abbas AM, Rubio-Casal AE, de Cires A, Figueroa E, Nieva JJ, Castillo JM (2014) Wrack burial reduces germination and establishment of the invasive cordgrass Spartina densiflora. In: Capdevila-Argüelles L, Zilletti B (Eds) Proceedings of 7th NEOBIOTA conference, Pontevedra, Spain. NeoBiota 21: 65-79. doi: 10.3897/neobiota.21.4963

Colautti RI, Parker JD, Cadotte MW, Pyšek P, Brown CS, Sax DF, Richardson DM (2014a) Quantifying the invasiveness of species. In: Capdevila-Argüelles L, Zilletti B (Eds) Proceedings of 7th NEOBIOTA conference, Pontevedra, Spain. NeoBiota 21: 7-27. doi: $10.3897 /$ neobiota. 21.5310

Colautti RI, Franks SJ, Hufbauer RA, Kotanen PM, Torchin M, Byers JE, Pyšek P, Bossdorf O (2014b) The Global Garlic Mustard Field Survey (GGMFS): challenges and opportunities of a unique, large-scale collaboration for invasion biology. In: Capdevila-Argüelles L, Zilletti B (Eds) Proceedings of 7th NEOBIOTA conference, Pontevedra, Spain. NeoBiota 21: 29-47. doi: $10.3897 /$ neobiota.21.5242

Kowarik I, Starfinger U (2009) Neobiota: a European approach. In: Pyšek P, Pergl J (Eds) Biological Invasions: Towards a Synthesis. Neobiota 8: 21-28.

Moralez-Silva E, Del Lama SN (2014) Colonization of Brazil by the cattle egret (Bubulcus ibis) revealed by mitochondrial DNA. In: Capdevila-Argüelles L, Zilletti B (Eds) Proceedings of 7th NEOBIOTA conference, Pontevedra, Spain. NeoBiota 21: 49-63. doi: 10.3897/ neobiota.21.4966 


\section{Supplementary material I}

Time to act! Biological invasions need a strong European legal framework urgently!

Authors: NEOBIOTA The European Group on Biological Invasions

Data type: image

Explanation note: Resolution adopted by the participants of the "7th European Conference on Biological Invasions" of the European Working Group on Biological Invasions - NEOBIOTA.

Copyright notice: This dataset is made available under the Open Database License (http://opendatacommons.org/licenses/odbl/1.0/). The Open Database License $(\mathrm{ODbL})$ is a license agreement intended to allow users to freely share, modify, and use this Dataset while maintaining this same freedom for others, provided that the original source and author(s) are credited.

Link: doi: 10.3897/neobiota.21.7289.app1 